\title{
ANALISIS WILLINGNESS TO PAY PELANGGAN AIR BERSIH PDAM DI KOTA KUPANG \\ (Analysis of Willingness to Pay Clean Water Customers of PDAM in Kupang City)
}

\author{
Tris Mesano Talahatu ${ }^{1 *}$, Marthen Robinson Pellokila² dan Johanis N. Kallau ${ }^{3}$ \\ ${ }^{1}$ Program Magister Ilmu Lingkungan, Universitas Nusa Cendana, \\ Jl. Adisucipto Penfui Kupang 85551. \\ ${ }^{2}$ Fakultas Pertanian, Universitas Nusa Cendana, Jl. Adisucipto Penfui Kupang 85551. \\ ${ }^{3}$ Fakultas Keguruan dan Ilmu Pendidikan, Universitas Nusa Cendana, \\ Jl. Adisucipto Penfui Kupang 85551.
}

*Penulis korespondensi. Tel: 081339438666. Email: tris_mesano2002@yahoo.com.

Diterima: 13 Juni 2017

Disetujui: 9 September 2017

\begin{abstract}
Abstrak
PDAM Kabupaten Kupang dalam mengelola pelayanan air bersih kepada masyarakat Kota Kupang menghadapi tantangan dalam pelayanannya. Salah satu permasalahan yang dihadapi PDAM adalah menyangkut tarif air minum. PDAM dalam menetapkan tarif selalu mengacu pada peraturan perundangan yang berlaku dengan pertimbangan tarif yang ada dapat memberikan keuntungan setelah biaya operasional dan pengembalian investasi. PDAM tidak pernah melakukan survey untuk mengetahui tingkat kesediaan konsumen dalam membayar tarif air minum. Penelitian ini bertujuan untuk mengestimasi nilai Willingness To Pay (WTP) pelanggan air bersih golongan rumah tangga di Kota Kupang dan menganalisis faktor-faktor yang secara signifikan mempengaruhi WTP pelanggan air bersih golongan rumah tangga di Kota Kupang. Metode penelitian yang digunakan adalah metode survey deskriptif dan teknik pengambilan sampel menggunakan kombinasi antara Area Sampling dan Proportionate Random Samplingdengan 250 responden. Metode valuasi kontingensi digunakan untuk mengetahui nilai WTP pelanggan air bersih. Nilai WTP pelanggan (individu) per bulan dalam membayar air bersih sebesar Rp. 145.489,46 sedangkan nilai total WTP untuk seluruh pelanggan PDAM Kabupaten Kupang golongan rumah tangga A (Rp 20.846 konsumen) per tahun sebesar Rp 36.394.479.684,00. Faktor-faktor yang berpengaruh signifikan terhadap WTP adalah tingkat pendapatan dan jumlah pemakaian air.
\end{abstract}

Kata kunci: air bersih, pemakaian air, kesediaan membayar, tingkat pendapatan,valuasi kontingensi.

\begin{abstract}
PDAM Kabupaten Kupang to manage clean water service always face challenges in its service. One of the problems that PDAM often faces is the tariff of drinking water. The PDAM in determining the tariff always refers to the prevailing law and regulation with the consideration of the existing tariff can give profit after the operational cost and the return of investment. PDAM has never conducted a survey to find out how much the willingness of consumers in paying drinking water rates. This study aims to estimate the value of Willingness To Pay (WTP) of household clean water subscribers in Kupang City and to analyze the factors that significantly affect the WTP of household clean water subscribers in Kupang City. The research method used is descriptive survey method and sampling technique using a combination of sampling area and proportionate random sampling with 250 respondents. Contingency valuation method is used to know the value of PAP of clean water customer. WTP value of customer (individual) per month in paying clean water Rp. 145,489.46 while the total value of WTP for all customers of PDAM Kabupaten Kupang household class A (20,846 consumers) per year amounted to 36.394.479.684,00. Factors that have significant effect on the PAP are the level of income and the amount of water consumption.
\end{abstract}

Keywords: clean water, water consumption, contingency valuationincome level, willingness to pay.

\section{PENDAHULUAN}

Air minum merupakan salah satu kebutuhan dasar bagi kualitas dan keberlanjutan kehidupan manusia, mutlak harus tersedia dalam kuantitas dan kualitas yang memadai. Pada hakekatnya, alam telah menyediakan air minum yang dibutuhkan, namun desakan pertumbuhan penduduk serta aktivitasnya telah menimbulkan berbagai dampak perubahan tatanan dan keseimbangan lingkungan. Daya dukung air baku yang semakin terbatas, karena pencemaran air, pengelolaan daerah tangkapan air kurang baik dan adanya perubahan iklim, merupakan isu lingkungan yang penting untuk ditangani. Di lain pihak, ketersediaan air pada suatu wilayah akan mendorong peningkatan ekonomi di wilayah tersebut karena pusat pertumbuhan di suatu wilayah hanya akan terjadi 
bila didukung sarana dan prasarana dasar, termasuk sarana dan prasarana air minum.

Pemerintah harus bertanggungjawab dalam pengembangan sarana dan prasarana air minum. Sejak awal tahun 1979 sampai dengan saat ini penyediaan air minum khususnya melalui jaringan perpipaan telah dibangun dan dikembangkan dengan menggunakan berbagai pendekatan baik bersifat sektoral maupun pendekatan keterpaduan dan kewilayahan (perkotaan dan perdesaan). Pada awalnya, pengembangan Sistem Penyediaan Air Minum (SPAM) banyak dilakukan oleh pemerintah pusat, namun demikian sejalan dengan era desentralisasi dan perkembangan sosial politik dalam negeri, maka penyelenggaraan pengembangan SPAM menjadi urusan wajib pemerintah daerah. Hal ini selaras dengan amanat Undang-Undang Nomor 32 Tahun 2004 tentang Pemerintahan Daerah.

Saat ini sering dijumpai permasalahan ketersediaan air bersih akibat penurunan kualitas lingkungan hidup, pada sisi lain kebutuhan air bersih semakin meningkat. Mariyono dan Zambani (2015) melaporkan contoh dampak penggunaan air terhadap lingkungan hidup. Secara konsep, Pellokila (2013) menyatakan bahwa dengan semakin meningkatnya kebutuhan air dan terjadinya kelangkaan ketersediaan air, orang mulai terpancing untuk berpikir dan memandang air sebagai komoditas ekonomi. Seperti yang tercantum dalam Dublin Principles. Kelangkaan air dianggap sebagai peluang ekonomi. Bagi pihak pengelola air, kelangkaan air harus diatasi dengan efisiensi pemakaian, yang ditindaklanjuti dengan pembatasan pemakaian air dengan cara menaikkan nilai ekonomi air sehingga orang akan berhati-hati memakai air karena mahal. Saat sebagian orang tertarik untuk menjual air langsung sebagai barang komoditi, beberapa pemakai air lainnya mulai terganggu. Hal ini karena air juga digunakan untuk budidaya pertanian. Ketersediaan air juga akan dapat menunjang peningkatan produksi pangan, peningkatan pendapatan petani, lapangan pekerjaan dan ketahanan pangan. Untuk melakukan evaluasi terhadap permasalahan lingkungan seperti ini dapat dilakukan dengan pendekatan ekonomi. Hal ini juga telah banyak diulas oleh Hoehn dan Randall (1987) serta Coller dan Harrison (1995). Permasalahan serupa juga dilaporkan oleh Ulya dkk (2014) tentang kajian nilai ekonomi air terkait penggunaan air bersih dan penggunaan sektor lain, dalam kaitannya dengan kelestarian alam sekitar.

Perusahaan Daerah Air Minum (PDAM) Kabupaten Kupang merupakan salah satu Badan Usaha Milik Daerah (BUMD) milik Pemerintah Kabupaten Kupang yang menjalankan misi pelayanan air minum bagi masyarakat Kota Kupang dan Kabupaten Kupang. PDAM melayani jumlah pelanggan tercatat sampai dengan Desember 2015 sebanyak 32.970 Sambungan Rumah (SR), dengan total kapasitas produksi sebesar 527,5 L/detik, sedangkan jumlah air yang diproduksi mengalami penurunan setiap tahunnya. Sesuai data yang diperoleh dari PDAM Kabupaten Kupang, produksi air pada tahun 2013-2016 yaitu sebesar 8.753.716; 8.154.809; 7.276.589; dan 5.460.006 $\mathrm{m}^{3}$ (PDAM Kupang, 2017). Penurunan produksi air ini disebabkan beberapa faktor seperti berkurangnya daerah tangkapan hujan (cathment area) di sekitar mata air akibat peralihan fungsi lahan dari hutan (pepohonan) menjadi perumahan.

Salah satu mekanisme yang seringkali menimbulkan masalah adalah proses di mana harga air dipatok dan didistribusikan kepada konsumen secara sepihak. Dalam kasus ini ada campur tangan politik dan sosial dalam menentukan harga air bersih PDAM di setiap daerah. Adanya campur tangan politik dan sosial tersebut tercemin dalam bentuk perundang-undangan ataupun peraturan yang mendorong air bersih dipatok pada tingkat harga tertentu. Pemerintah memberikan kewenangan kepada PDAM untuk menentukan harga air bersih yang didistribusikan pada tingkat dimana harga yang ditentukan dapat memberikan keuntungan setelah biaya operasional dan pengembalian investasi. Sekalipun status PDAM adalah merupakan perusahaan publik, akan tetapi sebagai pemasok air bersih yang memonopoli usaha pengadaan air bersih di daerah, PDAM dalam menetapkan harga air bersih yang dijual kepada konsumen atau pelanggannya ditentukan secara sepihak, artinya tidak melibatkan masukan dari masyarakat atau konsumennya. Dengan kata lain bahwa PDAM dalam menetapkan harga air bersih belum menginternalisasikan keinginan (kemauan) membayar dari para konsumen (Willingness To Pay, WTP) sebagai data yang melengkapi penentuan tarif (Winarna, 2003). Penggunaan WTP untuk analisis kemampuan pembayaran air juga telah dilakukan oleh Irawan (2009) dan Ifabiyi (2011).

WTP ini dapat menjadi metode yang diterapkan oleh PDAM di berbagai kota termasuk Kupang. Hal ini karena sangat berkaitan dengan isu tingkat harga dalam penyediaan air bersih dan pelayanan oleh pengelola air bersih di beberapa daerah Dengan WTP maka dapat dikaji nilai air yang seharusnya untuk dapat memenuhi kebutuhan biaya baik dari sisi produsen maupun dari sisi konsumen. Pada tingkat harga rendah, nilai air rendah, sehingga kebutuhan air bersih akan meningkat. Selama harga air setiap satu satuan lebih rendah dari nilainya, maka kebutuhan akan air terus meningkat sampai melebihi pasokan air yang 
tersedia. Pada tingkat ini, nilai air akan naik dan harga air juga akan naik. Sehingga semakin banyak kebutuhan konsumsi air bersih dan semakin sedikit persoalan air bersih yang tersedia, nilai setiap satu satuan air akan naik seiring dengan kenaikan harga sampai pada titik di mana jumlah air bersih yang dibutuhkan sama dengan pasokan air yang tersedia. Pada titik ini terdapat kesamaan antara kesanggupan membayar (WTP) dengan harga air (Kahn, 1995).

Tujuan penelitian ini adalah mengestimasi nilai WTP pelanggan air bersih golongan rumah tangga di Kota Kupang dan menganalisis faktorfaktor yang secara signifikan mempengaruhi WTP pelanggan air bersih golongan rumah tangga di Kota Kupang.

\section{METODE PENELITIAN}

\section{Waktu dan Lokasi}

Penelitian ini dilaksanakan selama 3 bulan mulai dari bulan November 2016-Februari 2017. Lokasi penelitian adalah seluruh wilayah Kota Kupang yang mendapatkan pelayanan air bersih dari PDAM Kabupaten Kupang. Terdapat enam kecamatan yaitu Kecamatan Alak, Maulafa, Oebobo, Kota Raja, Kelapa Lima dan Kota Lama.

\section{Jenis Penelitian}

Penelitian ini merupakan survey dengan metode deskriptif analitis. Metode survey deskriptif adalah suatu metode penelitian yang mengambil sampel dari suatu populasi dan menggunakan kuesioner sebagai alat pengumpulan data. Dalam penelitian ini data dan informasi dikumpulkan dari responden dengan menggunakan kuesioner. Setelah data diperoleh kemudian hasilnya dipaparkan secara deskriptif dan dianalisis untuk menguji hipotesis yang diajukan pada awal penelitian ini (Effendi, 2003).

\section{Populasi dan Teknik Pengambilan Sampel}

Populasi dalam penelitian ini adalah pelanggan PDAM Kabupaten Kupang golongan Rumah Tangga A yang berdomisili di wilayah Kota Kupang yang terdiri dari 20.846 SR (Sambungan Rumah). Adapun teknik pengambilan sampel menggunakan kombinasi antara Area Sampling dan Proportionate Random Sampling. Pengambilan sampel berdasarkan wilayah pelayanan PDAM Kabupaten Kupang (6 kecamatan) dan dari jumlah populasi yang ada diambil jumlah sampel sesuai prosentasenya, pengambilan sampel di lakukan secara acak.

Penentuan jumlah sampel mengacu pada rumus Slovin:

$$
n=\frac{N}{1+N e^{2}}
$$

Dalam hal ini :

$\mathrm{n} \quad$ : jumlah sampel

$\mathrm{N} \quad$ : jumlah populasi

e : batas toleransi kesalahan (error tolerance)

Berdasarkan persamaan (1) maka didapat jumlah sampel sebanyak 392. Dari jumlah sampel 392 tersebut yang diambil dalam penelitian ini sebanyak 250 pelanggan PDAM golongan Rumah Tangga A. Hal ini dipilih dengan pertimbangan bahwa kebanyakan penelitian pada umumnya ukuran sampel yang digunakan adalah antara 30 sampai dengan 500 (Sekaran, 1992).

\section{Analisis Data}

Analisis data dilakukan untuk mengestimasi besarnya nilai WTP pelanggan dalam membayar air bersih. Nilai rata-rata yang akan dikeluarkan oleh responden yang bersedia membayar dihitung dengan menggunakan persamaan (Pearce dan Turner, 1989) :

$$
A W T P=\frac{\sum_{i=1}^{\mathrm{n}} W i}{n}
$$

Dalam hal ini :

$$
\begin{array}{ll}
\text { A WTP } & =\text { Rata-rata nilai WTP responden } \\
\mathrm{Wi} & =\text { Nilai WTP yang bersedia dibayarkan } \\
\mathrm{i} & =\text { Responden yang bersedia membayar } \\
\mathrm{n} & =\text { Jumlah responden }
\end{array}
$$

\section{Menentukan Total TWTP}

Total WTP dapat digunakan untuk menduga WTP populasi secara keseluruhan dengan rumus (Pearce dan Turner, 1989) :

$$
\text { TWTP }=\sum_{i=1}^{n} W T P i\left\{\frac{n i}{N}\right\}_{x P}
$$

Dalam hal ini :

TWTP $=$ kesediaan populasi untuk membayar (total WTP)

WTPi = kesediaan responden untuk membayar ni = jumlah responden yang bersedia membayar sebesar WTP W $_{i}$

$\mathrm{N}$ = jumlah sampel

$\mathrm{P} \quad=$ jumlah populasi (pelanggan PDAM)

$\mathrm{i}=$ responden ke-i yang bersedia membayar $(\mathrm{i}=$ $1,2, \ldots, \mathrm{n})$

\section{Analisis Faktor-Faktor yang Mempengaruhi Kesediaan Membayar}

Fungsi WTP dalam penelitian ini disusun dari beberapa variabel yang diduga mempengaruhi nilai WTP pelanggan PDAM. Analisis yang digunakan adalah uji regresi linier berganda, karena variabel yang diuji lebih dari satu variabel. Persamaan 
regresi yang digunakan untuk mengestimasi nilai WTP berdasarkan faktor-faktor yang telah disebutkan adalah :

$$
\begin{aligned}
& \underline{\ln W T P}=\beta_{0}+\beta_{1} \ln X_{1 \mathrm{i}}+\beta_{2} \ln X_{2 \mathrm{i}}+\beta_{3} \ln X_{3 \mathrm{i}}+\beta_{4} \ln X_{4 \mathrm{i}}+\beta_{5} \ln X_{5 \mathrm{i}}+\beta_{6} \ln X_{6 \mathrm{i}}+ \\
& \beta_{7} \ln X_{7 \mathrm{i}}-\beta_{8} X_{8}+\mathrm{e}
\end{aligned}
$$

Dalam hal ini :

WTP = Rata-rata WTP pelanggan dalam membayar air bersih (Rp/bulan)

$\beta_{0}=$ Konstanta

$\beta_{1}, \beta_{2, \ldots} \beta_{8} \quad=$ Koefisien regresi

$\mathrm{X}_{1}=$ Jumlah anggota rumah tangga (jiwa)

$\mathrm{X}_{2}=$ Umur responden (tahun)

$\mathrm{X}_{3}=$ Tingkat pendidikan responden

$\mathrm{X}_{4}=$ Tingkat pendapatan responden (rupiah)

$\mathrm{X}_{5}=$ Penilaian masyarakat terhadap pelayanan PDAM

$\mathrm{X}_{6}=$ Tingkat pengetahuan masyarakat pengguna tentang tarif yang ditetapkan oleh Pihak Pengelola

$\mathrm{X}_{7} \quad$ =Jumlah pemakaian air $\left(\mathrm{m}^{3}\right)$

$\mathrm{X}_{8}=$ Ada tidaknya sumber air lain di luar PDAM (dummy)

$\ln =$ Logaritma natural

$\mathrm{i}=$ Responden ke-i

e $\quad$ Galat

Taraf signifikan (kesalahan) yang digunakan adalah $10 \%$ atau $\alpha=0,10$. Untuk mendapatkan hasil perhitungan berdasarkan persamaan (4) maka penulis menggunakan program SPSS. Pengujian hipotesis regresi linier berganda dilakukan dengan uji t dan uji F.

\section{HASIL DAN PEMBAHASAN}

\section{Memperkirakan Nilai Rata-Rata WTP}

Berdasarkan hasil wawancara dengan responden diperoleh nilai kesediaan membayar untuk setiap blok konsumsi air, yaitu untuk pemakaian air $0-10 \mathrm{~m}^{3}, 10-20 \mathrm{~m}^{3}$ dan di atas $20 \mathrm{~m}^{3}$, pembagian blok konsumsi air ini sesuai dengan Keputusan Bupati Kupang Nomor : 239/KEP/HK/2014, tentang Tarif Air Minum PDAM Kabupaten Kupang, untuk golongan pelanggan kelompok non niaga (rumah tangga A). Dari nilai kesediaan membayar responden kemudian dirata-ratakan, sehingga diperoleh nilai rata-rata kesediaan membayar untuk setiap blok konsumsi air (Tabel 1). Kemudian dilakukan regresi sederhana, dari hasil regresi kemudian diintegralkan dan didapat nilai WTP per responden. Hasil regresi sederhana dapat dilihat pada Gambar 1. Dari hasil analisis regresi sederhana diperoleh persamaan $Y=9399-303,6 X_{1}$. Jika $Y=0$, maka diperoleh $\mathrm{X}=30,96$. Berdasarkan hasil perhitungan tersebut maka dapat digambarkan dalam Gambar 2. Dengan mengintegrasikan persamaan garis regresi maka diperoleh nilai WTP per individu per bulan sebesar Rp. 145.489,46.

Tabel 1 Nilai rata-rata kesediaan membayar responden per blok konsumsi air

\begin{tabular}{lrrr}
\hline \multirow{2}{*}{ Uraian } & \multicolumn{3}{c}{ WTP per blok konsumsi air } \\
\cline { 2 - 4 } & \multicolumn{1}{c}{$0-10 \mathrm{~m}^{3}$} & $10-20 \mathrm{~m}^{3}$ & $>20 \mathrm{~m}^{3}$ \\
\hline Jumlah total & $2.144,30$ & 923 & 596 \\
Rata-rata WTP & $8.457,20$ & $3.692,00$ & $2.384,00$ \\
Rata-rata kubikasi $\left(\mathrm{m}^{3}\right)$ & 5 & 15 & 25 \\
\hline Sum
\end{tabular}

Sumber : Hasil analisis (2017)

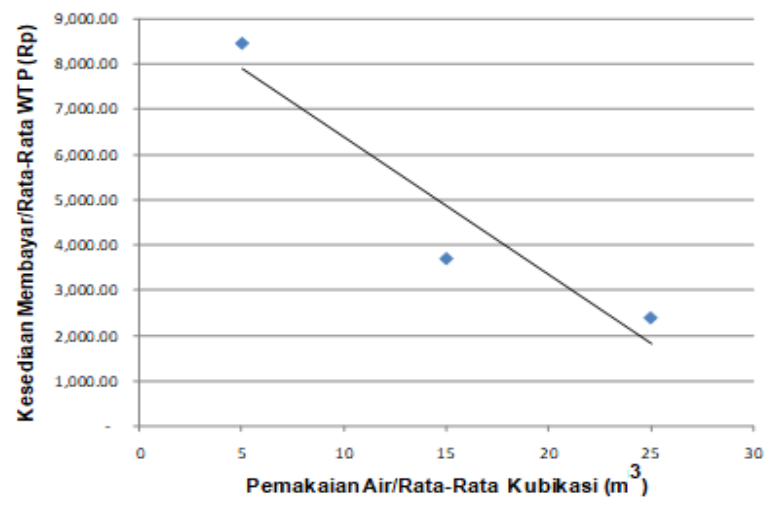

Gambar 1. Kurva regresi perhitungan WTP.

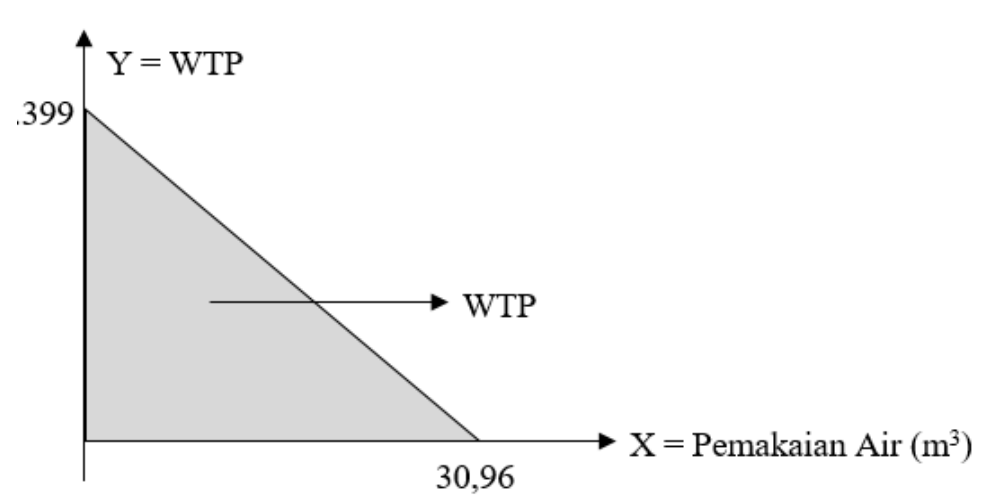

Gambar 2. Penentuan luas area di bawah grafik WTP 
Tabel 2. Nilai total WTP membayar air

\begin{tabular}{ccccc}
\hline $\begin{array}{c}\text { Rata-Rata A WTP } \\
\text { per Responden }\end{array}$ & $\begin{array}{c}\text { Jumlah } \\
\text { Resonden } \\
(\mathrm{KK})\end{array}$ & $\begin{array}{c}\text { Total WTP } \\
\text { Responden } \\
(\mathrm{Rp})\end{array}$ & $\begin{array}{c}\text { Jumlah } \\
\text { Populasi } \\
(\mathrm{KK})\end{array}$ & $\begin{array}{c}\text { Total WTP } \\
\text { Populasi } \\
(\mathrm{Rp})\end{array}$ \\
\hline $145.489,46$ & 250 & 36.372 .365 & 20.846 & 3.032 .873 .307 \\
\hline
\end{tabular}

Sumber : Hasil Analisis, 2017

Tabel 3. Hasil analisis regresi faktor-faktor yang mempengaruhi kesediaan pelanggan dalam membayar air bersih

\begin{tabular}{|c|c|c|c|c|c|}
\hline \multirow[t]{2}{*}{ Variabel } & \multicolumn{2}{|c|}{$\begin{array}{l}\text { Undstandardized } \\
\text { Coefficients }\end{array}$} & \multirow[t]{2}{*}{$\begin{array}{c}\text { Standarddized } \\
\text { Coefficients } \\
\end{array}$} & \multirow[t]{2}{*}{ t-hitung } & \multirow[t]{2}{*}{ Sig. } \\
\hline & $\mathrm{B}$ & Std. Error & & & \\
\hline (Constant) & 63267,426 & 35709,6 & & 1,772 & 0,078 \\
\hline Jumlah anggota rumah tangga & 3170,366 & 2195,636 & 0,083 & 1,44 & 0,015 \\
\hline Umur & $-304,023$ & 345,469 & $-0,054$ & $-0,88$ & 0,038 \\
\hline Tingkat pendidikan & 10160,19 & 6971,315 & 0,092 & 1,457 & 0,146 \\
\hline Tingkat pendapatan & 0,007 & 0,004 & 0,116 & 1,803 & $0,073 *$ \\
\hline Peniaian terhadap pelayanan & $-6021,516$ & 14614,28 & $-0,024$ & $-0,412$ & 0,681 \\
\hline Tingkat pengetahuan tarif & 3634,797 & 9000,851 & 0,023 & 0,404 & 0,687 \\
\hline Jumlah pemakaian air & 3967,397 & 520,36 & 0,438 & 7,624 & $0,000^{*}$ \\
\hline Ada/tidaknya sumber lain diluar PDAM & $-3772,63$ & 14053,801 & $-0,016$ & $-0,268$ & 0,789 \\
\hline
\end{tabular}

Sumber : Hasil Analisis, 2017. Keterangan : * Signifikan pada $\alpha 10 \%$

\section{Perhitungan Surplus Konsumen}

Konsumen berharap memperoleh manfaat atau nilai dari barang yang dibeli dan dikonsumsinya. Total nilai atau manfaat yang diterima konsumen ditunjukkan oleh suatu daerah dibawah kurva permintaan. Namun tidak seluruh nilai atau manfaat itu dibayar sesuai dengan nilainya, karena dalam setiap pembelian/konsumsi, konsumen mendapat surplus konsumen (Suparmoko, 2012). Berdasarkan data yang diperoleh dari PDAM Kabupaten Kupang, besarnya biaya produksi (beban usaha) selama tahun 2015 sebesar Rp. 38.980.200.654,00 . Biaya produksi per bulan rata-rata Rp. 3.248.350.054,50. Apabila total jumlah pelanggan PDAM pada akhir tahun 2015 sebanyak 32.970 konsumen, sehingga diperoleh harga air yang dibayarkan konsumen per bulan sebesar Rp. 98.542,42. Dalam hal ini terjadi surplus konsumen untuk setiap bulan sebagai selisih nilai WTP dengan harga air yang dibayarkan Rp. 46.965,04.

\section{Estimasi Nilai Total WTP}

Berdasarkan persamaan (3) maka didapat nilai Total WTP seperti pada Tabel 2. Berdasarkan hasil perhitungan maka nilai WTP kesediaan membayar air untuk seluruh pelanggan PDAM Kabupaten Kupang golongan rumah tangga A per bulan sebesar Rp. 3.032.873.307, 00. Untuk nilai WTP dalam 1 tahun sebesar Rp. 36.394.479.684,00.

\section{Analisis Faktor-Faktor Yang Mempengaruhi Kesediaan Pelanggan}

Dalam penelitian ini terdapat delapan faktor yang dianalisis untuk mengetahui pengaruhnya terhadap kesediaan dalam membayar air bersih. Variabel tersebut adalah jumlah anggota rumah tangga (X1), umur (X2), tingkat pendidikan(X3), tingkat pendapatan (X4), penilaian terhadap pelayanan (X5), tingkat pengetahuan tarif (X6), jumlah pemakaian air (X7) dan ada/tidaknya sumber lain diluar PDAM (X8) . Berdasarkan hasil analisis data penelitian dengan regresi linear berganda (Tabel 3), maka diperoleh fungsi WTP sebagai berikut :

$$
\begin{aligned}
& \underline{\ln W T P}=63267.426+3170.366 \ln X_{1}-304.023 \ln X_{2}+10160.190 \ln X_{3}+0.007 \\
& \ln X_{4}-6021.516 \ln X_{5}+3634.797 \ln X_{6}+3967.397 \ln X_{7}-3772.630 \ln X_{8}
\end{aligned}
$$

Hasil analisis data menunjukkan bahwa terdapat dua variabel berpengaruh nyata terhadap besarnya WTP pada selang kepercayaan $90 \%$. Variabel yang berpengaruh nyata pada taraf $\alpha=0,1$ adalah variabel tingkat pendapatan dan jumlah pemakaian air dengan arah positif. Hal ini berarti semakin meningkatnya pendapatan dan jumlah pemakaian air responden rumah tangga maka akan meningkatkan WTP.

Variabel yang tidak berpengaruh nyata ada enam variabel, yaitu variabel jumlah anggota rumah tangga $\left(X_{1}\right)$, umur $\left(X_{2}\right)$, tingkat pendidikan $\left(X_{3}\right)$, penilaian terhadap pelayanan $\left(\mathrm{X}_{5}\right)$, tingkat pengetahuan tarif $\left(\mathrm{X}_{6}\right)$, ada/tidaknya sumber lain di luar PDAM $\left(\mathrm{X}_{8}\right)$. Keenam variabel diketahui tidak 
Tabel 4. Hasil pengujian Anova ${ }^{b}$

\begin{tabular}{llrlll}
\hline \multicolumn{1}{c}{ Model } & $\begin{array}{l}\text { Sum of } \\
\text { Squares }\end{array}$ & df & $\begin{array}{l}\text { Mean } \\
\text { Square }\end{array}$ & F & Siq. \\
\hline Regression & $3.53 \mathrm{E}+11$ & 8 & $4.41 \mathrm{E}+10$ & 9,607 & $0,000^{\mathrm{a}}$ \\
Residual & $1.11 \mathrm{E}+12$ & 241 & $4.59 \mathrm{E}+09$ & & \\
Total & $1.46 \mathrm{E}+12$ & 249 & & & \\
\hline
\end{tabular}

a. Prediktor : (Constant), Dummy, Pelayanan, Jlhangkk, Tktpenpatan, Pemakaian, Tarif, Umur, Tkpendidikan

b. Dependent Variable : WTP

Tabel 5. Hasil analisis koefisien determinasi faktor-faktor yang berpengaruh terhadap kesediaan pelanggan dalam membayar air bersih

\begin{tabular}{rrrrrr}
\hline Model & R & R Square & $\begin{array}{c}\text { Adjusted R } \\
\text { Square }\end{array}$ & $\begin{array}{c}\text { Std. Error of } \\
\text { The Estimate }\end{array}$ & $\begin{array}{r}\text { Durbin- } \\
\text { Watson }\end{array}$ \\
\hline 1 & $0,492^{\mathrm{a}}$ & 0,242 & 0,217 & 67734,75 & 1,447 \\
\hline
\end{tabular}

a. Predictors : (Constant), Dummy, Pelayanan, Jlhangkk, Tktpenpatan, Pemakaian, Tarif, Umur, Tkpendidikan

b. Dependent Variable : WTP

berpengaruh nyata karena mempunyai P-value yang besar melebihi selang kepercayaan yang digunakan pada penelitian ini yaitu $90 \%$.

Signifikansi variabel tingkat pendapatan dan jumlah pemakaian air secara parsial dapat dibuktikan dengan Uji t. Untuk menghitung t tabel dengan taraf nyata $(\alpha)$ sebesar $10 \%$ (uji 2 arah) dan derajat bebas $(\mathrm{df}=\mathrm{n}-\mathrm{k}), \mathrm{df}=250-9=241$, Jadi hasil $\mathrm{t}_{\text {tabel }}=1,653$. Nilai $\mathrm{t}_{\text {hitung }}$ untuk variabel tingkat pendapatan $=1,803$ yang lebih besar dari $t_{\text {tabel }}$ menunjukkan terdapat pengaruh yang signifikan secara parsial antara tingkat pendapatan terhadap kesediaan pelanggan dalam membayar air bersih. Sedangkan $t_{\text {hitung }}$ untuk variabel jumlah pemakaian air $=7,624$. Jadi Nilai $t_{\text {hitung }}$ lebih besar dari $t_{\text {tabel }}$, yang berarti menunjukkan pengaruh yang signifikan secara parsial antara jumlah pemakaian air terhadap kesediaan pelanggan dalam membayar air bersih.

Berdasarkan hasil ANOVA (Tabel 4), nilai $F_{\text {hitung }}$ sebesar 9,607 dengan nilai signifikan 0,000 menunjukan bahwa variabel-variabel penjelas dalam model secara bersama-sama berpengaruh nyata terhadap WTP (kesediaan pelanggan dalam membayar air bersih) pada taraf nyata $(\alpha=10 \%)$. Hal ini disebabkan $F_{\text {hitung }}>F_{\text {tabel }}$, di mana $F_{\text {tabel }}=$ 1,70 , pada taraf nyata $(\alpha=10 \%)$ dengan derajat kebebasan df $1=\mathrm{k}-1=9-1=8$ dan df $2=\mathrm{n}-\mathrm{k}=250-9$ $=241$, sedangkan $F_{\text {hitung }}=9,607$.

\section{Koefisien Determinasi}

Tabel 5 menunjukkan hasil analisis koefisien determinasi faktor-faktor yang berpengaruh terhadap kesediaan pelanggan dalam membayar air bersih. Berdasarkan Tabel 5 diperoleh nilai $\mathrm{R}$ atau koefisien korelasi sebesar 0,492 bernilai positif dengan tingkat hubungan cukup kuat, artinya derajat hubungan antara variabel bebas (independent) dengan variabel terikat (dependent) memiliki hubungan cukup kuat.

Nilai $\mathrm{R}$ square atau koefisien determinasi sebesar 0,242 artinya $24,2 \%$ variasi yang terjadi terhadap besar kecilnya kesediaan pelanggan dalam membayar air bersih dipengaruhi oleh jumlah anggota rumah tangga $\left(X_{1}\right)$, umur $\left(X_{2}\right)$, tingkat pendidikan $\left(\mathrm{X}_{3}\right)$, tingkat pendapatan $\left(\mathrm{X}_{4}\right)$, penilaian terhadap pelayanan $\left(\mathrm{X}_{5}\right)$, tingkat pengetahuan tarif $\left(\mathrm{X}_{6}\right)$,jumlah pemakaian air $\left(\mathrm{X}_{6}\right)$ dan ada/tidaknya sumber lain di luar PDAM $\left(\mathrm{X}_{8}\right)$, sedangkan sisanya sebesar 75,8\% dipengaruhi oleh galat (error) atau pengaruh variabel yang lain.

\section{KESIMPULAN}

Berdasarkan hasil analisis Willingness To Pay didapatkan nilai WTP pelanggan (individu) per bulan dalam membayar air bersih sebesar Rp. 145.489,46. Untuk nilai total WTP untuk seluruh pelanggan PDAM Kabupaten Kupang golongan rumah tangga $\mathrm{A}$ per tahun sebesar Rp 36.394.479.684,00.

Pengaruh yang signifikan secara parsial diketahui terjadi antara tingkat pendapatan dan jumlah pemakaian air terhadap kesediaan pelanggan dalam membayar air bersih. Variabel yang tidak berpengaruh nyata yaitu variabel jumlah anggota rumah tangga, umur, tingkat pendidikan, penilaian terhadap pelayanan), tingkat pengetahuan tarif, ada/tidaknya sumber lain di luar PDAM.

\section{DAFTAR PUSTAKA}

Coller M., and Harrison, G.W., 1995. On The Use of Contingent Valuation Method to Estimate 
Environmental Costs, in Advances in Accounting, ed by Phillip M.J. Reckers. New York : JAI Press, pp. 169-193

Hoehn, J., and Randall, A., 1987. A Satisfactory Benefit Cost Indicator from Contingent Valuation. J. Environmental Economics \& Management, 14 : 226-247.

Ifabiyi, I.P., 2011. Willingness To Pay for Water Household Level in Ilorin. Global Journal of Human Sosial Science. 11(2):17-18.

Irawan, B.B.R.M., 2009 Willingness To Pay dan Ability To Pay Pelanggan Rumah Tangga Sebagai Respon Terhadap Pelayanan Air Bersih dari PDAM Kota Surakarta. Journal Ekonomi dan Kebijakan, 2(1):29-43.Kahn, J.R., 1995, The Economic Approach to Environmental and Natural Resources. The Dryden Press.New York.

Mariyono, J., dan Zambani, M.A., 2015. Dampak Keberadaan Perusahaan Air Minum Dalam Kemasan di Klaten-Jawa Tengah Pada Situasi Perekonomian Masyarakat. J. Manusia \& Lingkungan, 22(2):142-150.

Pearce D. and Turner, K., 1989. Economics of Natural Resources and The Environment. Harvester Wheatsheaf, London.
Pellokila, M.R., 2013. Modul Mata Kuliah Ekonomi Sumberdaya Alam dan Lingkungan. Program Studi Ilmu Lingkungan Program Pascasarjana Universitas Nusa Cendana. Kupang.

Sekaran, U., 1992. Research Methods For Business: A Skill Building Approach, New York : John Wiley \& Sons Inc.

Suparmoko, M. 2012. Ekonomika Lingkungan. Fakultas Ekonomika dan Bisnis UGM. Yogyakarta.

Ulya, N.A., Warsito, S.P., Andayani, W., dan Gunawan, T., 2014. Nilai Ekonomi Air Untuk Rumah Tangga dan Transportasi - Studi Kasus di Desa-Desa Sekitar Hutan Rawa Gambut Merang Kepayang, Provinsi Sumatera Selatan. J. Manusia \& Lingkungan, 21(2):232-238.

Winarna, S. 2003. Analisis Konsumsi Air Bersih Pelanggan Rumah Tangga Berdasarkan Faktor-Faktor yang Mempengaruhi (Studi Kasus pada PDAM Kabupaten Karanganyar). Tesis. Program Pascasarjana Universitas Diponegoro, Semarang. 